\title{
Development of Chicken Nutritional Quality Classification Methods and Algorithms Eggs Based on Characteristics of Yellow Eggs
}

\author{
Juli Yanto ${ }^{1}$, Sarifuddin Madenda ${ }^{2}$ \\ ${ }^{1}$ STTI NIIT, \\ ${ }^{2}$ Gunadarma University \\ Email: julitomoko@gmail.com ${ }^{1}$, sarif@staff.gunadarma.ac.id ${ }^{2}$
}

Article History: Received: 10 November 2020; Revised: 12 January 2021; Accepted: 27 January 2021; Published online: 05 April 2021

\begin{abstract}
In order to sustain human life, food is a very necessary material, since the human body requires nutrition to be used in everyday activities. In this case, eggs are among the nutritional intake, a protein that is commonly consumed by the community, particularly native chicken eggs that are available quite a lot. The nutritional quality does have beneficial advantages for the human body in all areas of the egg. In eggs, 10.8 percent of the protein content the body requires is in egg whites and 16.3 percent in egg yolks. The consistency of the egg is defined by the yolk color strength. The principal characteristic of egg quality is the yolk color. There are three basic forms of widely discovered shades of egg yolk. Pale yellow, plain yellow and orange yellow. Vitamin A, vitamin B2, folic acid, vitamin B6, and vitamin B12, iron, calcium, phosphorus, potassium, and cholesterol are rich in vitamins and minerals in egg yolks. Using the object image of 30 egg yolks, the preprocessing process with the background image is then uniform in size and then grouped by color-dependent characteristics so that the nutritional quality can be identified and the attribute extract is grouped using matlab based on sample testing at the Broad Research and Implementation of Biotechnology BPPT Testing Laboratory The convolutional process of neural networks. Development of characteristic digital image-driven extraction of chicken egg yolk and implementation of nutritional quality grouping of eggs based on characteristic colour extraction of egg yolk. In yellow colour, chicken offers $94 \%$ similarity.
\end{abstract}

Index Terms: Convolution, Choroma luminan, Egg yolk, Feature Extraction, Neural Networks, Nutrition.

\section{Introduction}

One part of the egg that is the food of the embryo is egg yolk. Eggs contain nearly all the necessary nutrients that are required by the body. Vitamin A, vitamin B2, folic acid, vitamin B6, vitamin B12, iron, calcium, phosphorus, potassium and cholesterol are considered rich in vitamins and minerals (Salim 2012).

The consistency of eggs is primarily influenced by the yolk color strength. The yolk color is the key attribute of the consistency of the egg (Chung 2002). The colour of egg yolk influences customer preferences, with the favored ones commonly varying from golden yellow to orange. There are three kinds of widely occurring egg yolks. Pale yellow, slightly orange yellow, dark orange.

According to Helena, Vol. 32, 2014, No.3: 213-217, on the visual evaluation of egg yolk color with the usual La Roche scale, the darkest color was found in bio eggs while the darkest color was found in some special egg varieties, for example extra yolk or free breeder eggs range. The yolk color varies between the values 4-13 on the La Roche scale. In primary care, this technique is common as a basic tool to determine the consistency of yolk. A striking difference exists in the choice of consumers in different European countries for egg yolk color. Consumers in Germany, the Netherlands, Spain and Belgium prefer yellow with a La Roche scale score of 13-14, in France, South England and Finland with a La Roche scale score of 11-12, and in Ireland, Northern England and Sweden with a La Roche scale score of 8-9. (DSM 2011).

The method of indexing a collection of images and their content is feature extraction. Numerically, each extraction of features is an econdition of a feature vector termed an $\mathrm{n}$-dimensional vector. The part of the feature vector is computed by methods of image processing and analysis and is used to compare individual images with images.

Depending on the outcomes of the analysis of four color spaces, including HSL, HSV and L* $\mathrm{a}^{*} \mathrm{~b}^{*}$ or $\mathrm{L}^{*} \mathrm{C}^{*} \mathrm{H}^{*}$, the HCL color space (Hue, Chroma, Luminance) has been created. The benefits that occur in each color space are merged into this color space. This would contribute to a more uniform color space for visual perception by humans. 
The component in image color segmentation is to decide that pixels relate to the same segment and to evaluate the boundary between two segments with different color maps. You have to gauge the contrast between the different colors to do this. With relation to the 3-D color space coordinate model used, there are many color distance formulas that were created by researchers.

The color distance between two pixels can be measured for color spaces in Cartesian 3-D columns by the Euclidean distance method or city block distance (also defined as Manhatan distance), where (X1, Y1,) and (X2, $\mathrm{Y} 2$, ) are the color components of the first and second pixels, accordingly.

$$
\begin{aligned}
& \text { a. } \Delta \mathrm{E}=\sqrt{ }\left(\llbracket\left(\mathrm{X} \rrbracket-1-\mathrm{X} \_2\right)+\left(\mathrm{Y} \_1-\mathrm{Y} \_2\right)^{\wedge} 2\right) \\
& \text { b. } \Delta \mathrm{E}=\left|\mathrm{X} \_1-\mathrm{X} \_2\right|+\left|\mathrm{Y} \_1-\mathrm{Y} \_2\right|
\end{aligned}
$$

\section{Research Methods}

Using an image object of $30 \mathrm{egg}$ yolks, the research phases are carried out to obtain an image of egg yolk, then the preprocessing process with the background image and the enhanced image is taken out instead of analysing the color features, then the size is standardized and then clustered by features.

Based on color, so that the nutritional content could be displayed at the BPPT Lab based on sample testing. The Institute for Research and Application of Biotechnology Technology testing laboratory then decides the nutritional content based on the color of egg yolk with the same color value as the process of the Convolutin Neural Network, as shown in Figure 1.

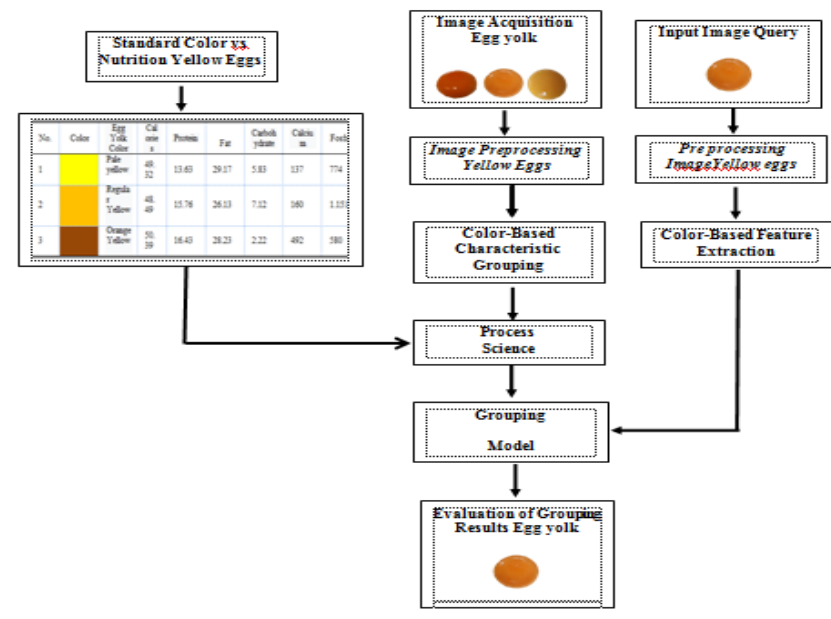

Figure 1. Research Steps

\subsection{Acquisition of Egg Yolk Image}

The object acquisition process uses the image of 40 egg yolks, the image of free-range chicken egg yolk is parsed so that the appearance of the egg yolk is visible which is then imaged using a 4: 3 qualifying 16 mega pixel mobile phone camera with pixel size (4608 x 3456) with a resolution of $1080 \times 2220$ by shooting from above. Furthermore, the egg image is matched with an egg yolk color fan to distinguish the three qualities of the egg yolk.

After doing 40 samples of egg yolk image acquisition. then the results obtained for each grade are as follows: 1. Yellow Orange (1-2 colors)

2. Ordinary Yellow (3-4 colors)

3.Pale Yellow (5-6 colors)

The following is an example of an original image based the egg yolk color category on. 


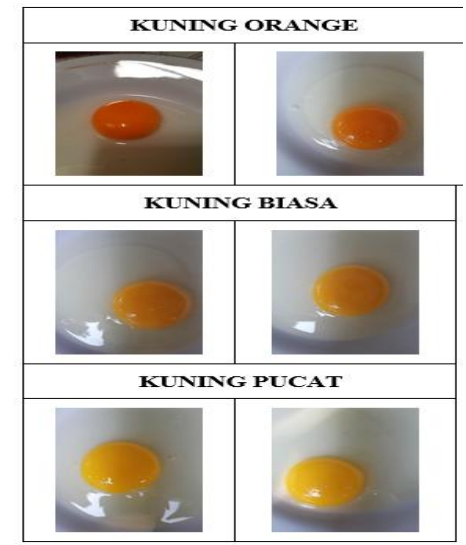

Figure 2. Original Egg Yolk Image

There is also an example of image acquisition as shown in Fig 3.

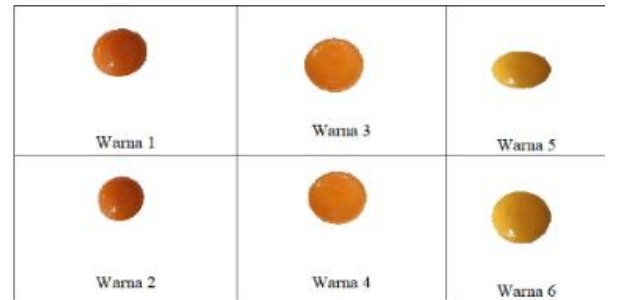

Figure 3. Image Acquisition Results

\subsection{Preprocessing of Egg Yolk Image}

Preprocessing requires steps to ensure the smooth running of the next process, including:

a. Image quality is improved (contrast, brightness, etc.)

b. Eliminates Noise

c. Image restoration

d. Transformation (image transformation)

e. Determine the part of the image to be observed

\subsection{Color-Based Characteristic Grouping}

Segmentation is the process of partitioning an image into multiple regions or objects. Image segmentation is generally based on discontinuity or similarity in pixel intensity. The purpose of discontinuity is to partition the image if there is a sudden (edge-based) change in intensity. While expecting similarity is to partition the image into regions that have certain characteristics (by region), for example: threshold, regional growth, regional separation and incorporation For image segmentation, it is done by croping the yolk and then the size is uniformed, using the application.

Before doing the feature extraction process and the stage of grouping egg quality based on egg yolk color. First, the yolk image must be uniform in image size. This is done because the image obtained by the image is not the same size and sometimes irregular. The uniform image size is expected to accelerate the further image processing. The image uniformity process is carried out in the following stages:

a. background disposal

b. yolk dropping

c. uniformity of size or pixels

The results of image uniformity with a size of $150 \times 150$ particles are shown in Fig 4. 


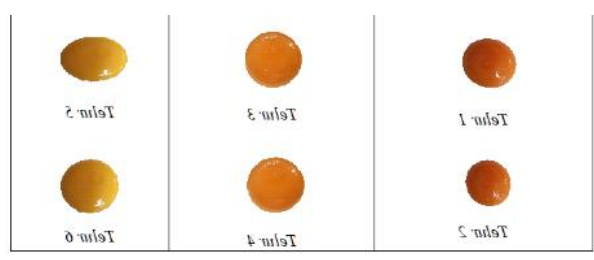

Figure 4. Uniform Image Results

\subsection{Science Process}

To obtain data from egg yolks for the grain value. At the BPPT Lab, research was carried out. Institute of Biotechnology Research Laboratory, Department for the Evaluation and Implementation of Technology. There are samples for each egg yolk color are shown in Table 1.

Table 1. Color Base D on Luminan

\begin{tabular}{|c|c|c|c|}
\hline \multicolumn{4}{|c|}{ "Egg Yolk Testing Samples } \\
\hline Information & $\begin{array}{c}\text { Bottle } \\
\text { Weight }\end{array}$ & $\begin{array}{l}\text { Number of } \\
\text { Egg Yolks }\end{array}$ & $\begin{array}{c}\text { Egg Yolk } \\
\text { Specific } \\
\text { Gravity }\end{array}$ \\
\hline Pale Egg Yolk & $\begin{array}{l}10.38 \\
\text { Gram }\end{array}$ & 3 Egg Yolks & 170 Gram \\
\hline $\begin{array}{l}\text { Regular Egg } \\
\text { Yolk }\end{array}$ & $\begin{array}{l}10.43 \\
\text { Gram }\end{array}$ & 3 Egg Yolks & 166 Gram \\
\hline $\begin{array}{l}\text { Orange Egg } \\
\text { Yolk }\end{array}$ & $\begin{array}{l}10.64 \\
\text { Gram }\end{array}$ & 3 Egg Yolks & 168 Gram \\
\hline
\end{tabular}

Furthermore, the color value and giji value content of each egg yolk image are shown in Table 2.

Table 2. The nutritional value of egg yolk is based on the color value of the egg yolk image

\begin{tabular}{|c|c|c|c|c|c|c|c|c|}
\hline No. & Color & $\begin{array}{c}\text { Egg Yolk } \\
\text { Color }\end{array}$ & Calories & Protein & Fat & Carbohydrate & Calcium & Fosfor \\
\hline 1 & & Pale yellow & 49.32 & 13.63 & 29.17 & 5.83 & 137 & 774 \\
\hline 2 & & $\begin{array}{l}\text { Regular } \\
\text { Yellow }\end{array}$ & 48.49 & 15.76 & 26.13 & 7.12 & 160 & 1.151 \\
\hline 3 & & $\begin{array}{l}\text { Orange } \\
\text { Yellow }\end{array}$ & 50.39 & 16.43 & 28.23 & 2.22 & 492 & 580 \\
\hline
\end{tabular}

2.5. Determining the Extraction Characteristics of Egg Yolk Image by Color the results of the Extraction Characteristics of Egg Yolk Image using matlab is shown in Table 1.

\begin{tabular}{|c|c|c|c|c|c|c|c|c|c|c|c|c|c|c|c|c|c|c|}
\hline \multicolumn{7}{|c|}{ 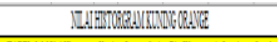 } & \multicolumn{6}{|c|}{ 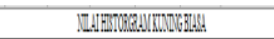 } & \multicolumn{6}{|c|}{ 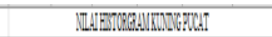 } \\
\hline 74861311. & 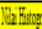 & allo & $\bar{h}$ & $\mathrm{Shan}_{2}$ & dilm & & T.32 & & $2 \operatorname{lin}$ & bing? & $\overline{T i m a z}$ & ens:l: & 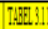 & $\overline{V i n i n}$ & alim & ahizy & Tmang & mingl: \\
\hline Ba: & & & & l & & & & & & at & & & & & & $\mathrm{mal}$ & & \\
\hline$\pi_{z z}$ & 0 & 1 & $?$ & 1 & t & f & 1 & 1 & $?$ & 1 & 4 & i & 1 & 1 & $?$ & 1 & 4 & i \\
\hline & Getir: & & & & & & Gatre: & & & & & & (Grizle & & & & & \\
\hline 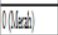 & 0 & 1 & 1 & 1 & 1 & 1 & 1 & 1 & 0 & 1 & 0 & 1 & 1 & 1 & 1 & 1 & 0 & 0 \\
\hline $1(1 \mathrm{rg})$ & 0 & 1 & 1 & 1 & 1 & 1 & 1 & 0 & 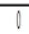 & 1 & 0 & 1 & 1 & 1 & 0 & 1 & 0 & 0 \\
\hline (iming & 0 & 1 & 1 & 1 & 1 & 1 & 1 & 1 & 0 & 1 & 0 & 1 & 1 & 1 & 0 & 1 & 0 & 0 \\
\hline (Fwhing & 1 & 1 & 1 & 1 & 1 & 1 & 1 & 1 & 0 & 1 & 0 & 1 & 1 & 1 & 1 & 7 & 0 & 0 \\
\hline$\sqrt{4(5 a x)}$ & 0 & 1 & 1 & 1 & 1 & 1 & 1 & 1 & 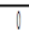 & 1 & 0 & 1 & 1 & 1 & 0 & 1 & 0 & 0 \\
\hline $5(5 \mathrm{~g} / \mathrm{h} / \mathrm{a})$ & 0 & 1 & 1 & 1 & 1 & 1 & 1 & 1 & 0 & 1 & 0 & 1 & 1 & 1 & 0 & 1 & 0 & 0 \\
\hline $6(\mathrm{Gz})$ & 0 & 1 & 1 & 1 & 1 & 1 & 1 & 1 & 1 & 1 & 1 & 1 & 1 & 1 & 1 & 1 & 0 & 0 \\
\hline $7($ basias) & 0 & 1 & 1 & 1 & 1 & 1 & 1 & 0 & 1 & 1 & 1 & 1 & 1 & 1 & 0 & 7 & 1 & 0 \\
\hline $8(3 x)$ & 0 & 1 & 1 & 1 & 1 & 1 & 1 & 0 & 0 & 1 & 1 & 1 & 1 & 1 & 0 & 1 & 0 & 0 \\
\hline $9 \sin \sqrt{2} g)$ & 0 & 1 & 1 & 1 & 1 & 1 & 1 & 0 & 0 & 1 & 0 & 1 & 1 & 1 & 0 & 1 & 0 & 0 \\
\hline $10(19)$ & 0 & 1 & 1 & 1 & 0 & 1 & 1 & 0 & 0 & 1 & 1 & 1 & 1 & 1 & 1 & 1 & 0 & 0 \\
\hline $11(\log ) / \ln 2$ & 2. 1 & 1 & 1 & 1 & 1 & 1 & 1 & 0 & 1 & 1 & 1 & 1 & 1 & 1 & 1 & 1 & 0 & 0 \\
\hline
\end{tabular}




\section{Conclusion:}

2.3. From the $\mathrm{L} 1$ analysis of the orange and yellow colors above, it can be concluded that the respective Hue $(\mathrm{H})$ values are 0 . So there is no difference between each Hue $(\mathrm{H})$ or there is no dominant color.

2.3. So the comparison of the results of the usual yellow L1 above is the same, resulting in a Luminance of 0 2.3. So from the results of the pale yellow L1 analysis it can be concluded that there is no difference for each Hue, the number is the same, namely 0.

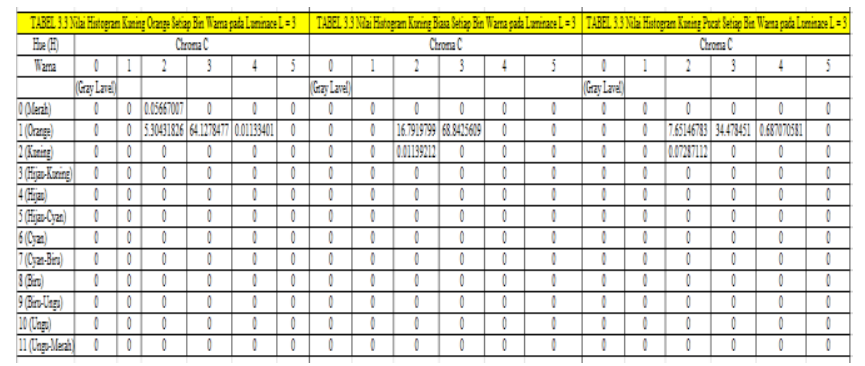

\section{Conclusion:}

1) From the results of the orange yellow L3 analysis above, it can be concluded that the red Hue $(\mathrm{H})$ value is 0.056670067 and the orange Hue $(\mathrm{H})$ value is 69.44349994 . Therefore, from L3 yellow orange the dominant colors are red and orange with a total of 69,50017001.

2) In the normal yellow L3 table above, it will see that the result of Orange Hue $(H)$ generates luminance with a result of 85.6345309 and the result of Yellow Hue $(\mathrm{H})$ generates luminance with a result of 0.011392117 . The other luminance is 0 , so the sum of 85.64593301 is Luminance L3.

3) From the results of the pale yellow L3 analysis above, it can be concluded that there are 2 dominant values, namely Hue (red) and Hue (orange), the Luminance Hue (red) value of 0.056670067 and Hue (orange) of 69.44349994.

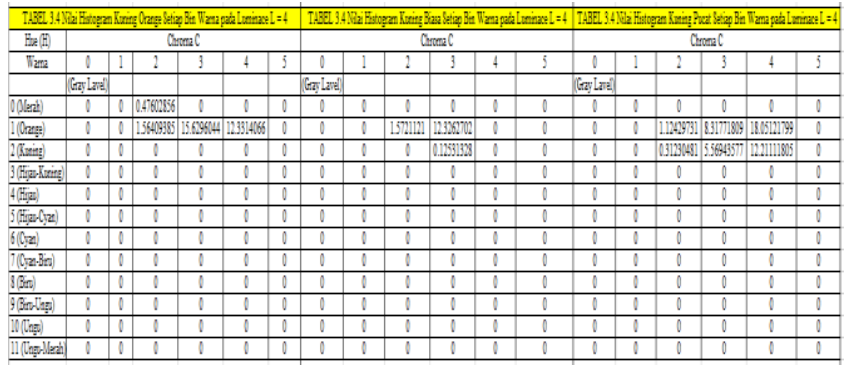

\section{Conclusion:}

1) From the results of the orange yellow L4 analysis above, it can be concluded that each Hue (H) value is 0 . So there is no difference between each Hue $(\mathrm{H})$ or there is no dominant color.

2) We can see in the usual yellow L4 table above that the Orange Hue $(\mathrm{H})$ value produces Luminance with a value of 13.89838232 and the Yellow Hue $(H)$ value produces Luminance with a value of 0.0125313283. Another luminance is 0, then the total Luminance L4 is 14.0236956.

3) From the results of the pale yellow L4 analysis above, the orange hue has a value of 27.4932334 and the yellow hue is 18.09285863 . This is because the colors that dominate are the orange and yellow hues.

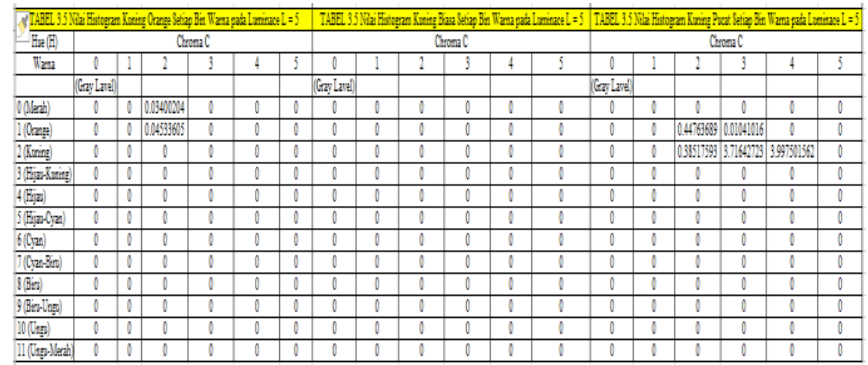




\section{Conclusion:}

1) From the results of the L5 yellow orange data analysis above, it can be concluded that the red Hue (H) has a value of 0.03400204 and Hue orange $(\mathrm{H}) 0.045336053$. Therefore, the yellow colors that dominate L5 orange are red and orange for a total of 0.079338094 .

2) So the comparison of the results of the usual yellow L5 above is the same, resulting in a Luminance of 0.

3) From the pale yellow L3 analysis above, it can be concluded that there are 2 dominant values, namely Hue (red) and Hue (orange), the Luminance Hue (red) value of 0.03400204 and Hue (orange) of 0.045336053 .

\section{Result And Discussion}

\subsection{Results of Distribution from RGB Images to HCL}

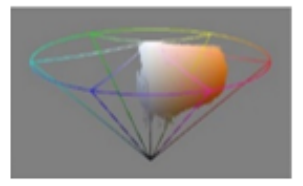

Figure 5. Distribution of Orange Egg Yolk

\section{Conclusion:}

The distribution of orange egg yolk is more dominant towards dark red with a semicircular shape accompanied by orange, while for the yellow color there is less gray and ping in a rectangular shape, while the color mixed with white mixed with black and greenish colors forms less larger rectangle shape color.

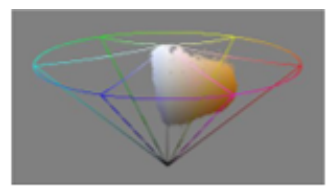

Figure 6. Distribution of Regular Egg Yolk

\section{Conclusion:}

The distribution of ordinary egg yolks is more dominant in the direction of light orange mixed with yellow, while to a little red and has a grayish color mixed with yellow so that the color on top has a white color underneath it has a green shape in each color almost like a triangular hemisphere. Equilateral.

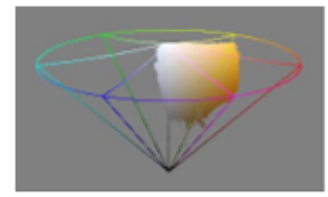

Figure 7. Distribution of Pale Yolk

\section{Conclusion:}

The distribution of the pale egg yolk is more dominant in the direction of yellow, while the oranges are less and the red is mixed with brown for the gray mixed with white, but the white tends to be more than the gray in this picture the top list has a line white and the image forms in this pale yolk like a trapezium.

\subsection{Color Table by Luminan}

Table Luminance Value of egg yolk from red, orange and yellow juxtaposed.

Table 3. Color base d on luminan

\begin{tabular}{|c|c|c|c|c|c|}
\hline $\begin{array}{c}\text { Tabel } \\
\text { Ciri }\end{array}$ & \multirow{2}{*}{$\begin{array}{l}\text { Luminan dan } \\
\text { Choroma }\end{array}$} & \multicolumn{4}{|c|}{ Warna Kuning Telur } \\
\hline No & & Ciri Warna & Warna Kuning & Warna Kuning & Warna Kuning \\
\hline
\end{tabular}


Development of Chicken Nutritional Quality Classification Methods and Algorithms Eggs Based on Characteristics of Yellow Eggs

\begin{tabular}{|c|c|c|c|c|c|}
\hline & & Kuning Telur & Telur Oranye & Telur Biasa & Telur Pucat \\
\hline 1 & $\mathrm{~L} 2 \mathrm{C} 2$ & Warna Merah & 0 & 0 & 0 \\
\hline 2 & L2C3 & Warna Merah & 0 & 0 & 0 \\
\hline 3 & $\mathrm{~L} 2 \mathrm{C} 4$ & Warna Merah & 0 & 0 & 0 \\
\hline 4 & L2C5 & Warna Merah & 0 & 0 & 0 \\
\hline 5 & L3C2 & Warna Merah & 0 & 0 & 0 \\
\hline 6 & L3C3 & Warna Merah & 0.056670067 & 0 & 0 \\
\hline 7 & L3C4 & Warna Merah & 0 & 0 & 0 \\
\hline 8 & L3C5 & Warna Merah & 0 & 0 & 0 \\
\hline 9 & $\mathrm{~L} 4 \mathrm{C} 2$ & Warna Merah & 0 & 0 & 0 \\
\hline 10 & L4C3 & Warna Merah & 0.476028562 & 0 & 0 \\
\hline 11 & $\mathrm{~L} 4 \mathrm{C} 4$ & Warna Merah & 0 & 0 & 0 \\
\hline 12 & L4C5 & Warna Merah & 0 & 0 & 0 \\
\hline 13 & L5C2 & Warna Merah & 0 & 0 & 0 \\
\hline 14 & L5C3 & Warna Merah & 0.03400204 & 0 & 0 \\
\hline 15 & L5C4 & Warna Merah & 0 & 0 & 0 \\
\hline 16 & L5C5 & Warna Merah & 0 & 0 & 0 \\
\hline 17 & $\mathrm{~L} 2 \mathrm{C} 2$ & Warna Orange & 0 & 0 & 0 \\
\hline 18 & L2C3 & Warna Orange & 0.408024481 & 0.318979266 & 2.95648553 \\
\hline 19 & $\mathrm{~L} 2 \mathrm{C} 4$ & Warna Orange & 0 & 0 & 0 \\
\hline 20 & L2C5 & Warna Orange & 0 & 0 & 0 \\
\hline 21 & L3C2 & Warna Orange & 0 & 0 & 0 \\
\hline 22 & L3C3 & Warna Orange & 5.304318259 & 16.79197995 & 7.651467833 \\
\hline 23 & L3C4 & Warna Orange & 64.12784767 & 68.84256095 & 34.47845097 \\
\hline 24 & L3C5 & Warna Orange & 0.011334013 & 0 & 0.687070581 \\
\hline 25 & $\mathrm{~L} 4 \mathrm{C} 2$ & Warna Orange & 0 & 0 & 0 \\
\hline 26 & L4C3 & Warna Orange & 1.564093846 & 1.572112098 & 1.124297314 \\
\hline 27 & $\mathrm{~L} 4 \mathrm{C} 4$ & Warna Orange & 15.62960444 & 12.32627022 & 8.317718093 \\
\hline 28 & L4C5 & Warna Orange & 12.33140655 & 0 & 8.317718093 \\
\hline 29 & L5C2 & Warna Orange & 0 & 0 & 0 \\
\hline 30 & L5C3 & Warna Orange & 0.045336053 & 0 & 0.447636894 \\
\hline 31 & $\mathrm{~L} 5 \mathrm{C} 4$ & Warna Orange & 0 & 0 & 0.01041016 \\
\hline 32 & L5C5 & Warna Orange & 0 & 0 & 0 \\
\hline 33 & $\mathrm{~L} 2 \mathrm{C} 2$ & Warna Kuning & 0 & 0 & 0 \\
\hline 34 & $\mathrm{~L} 2 \mathrm{C} 3$ & Warna Kuning & 0 & 0 & 0 \\
\hline 35 & L2C4 & Warna Kuning & 0 & 0 & 0 \\
\hline 36 & L2C5 & Warna Kuning & 0 & 0 & 0 \\
\hline 37 & L3C2 & Warna Kuning & 0 & 0 & 0 \\
\hline 38 & L3C3 & Warna Kuning & 0 & 0.011392117 & 0.072871122 \\
\hline 39 & L3C4 & Warna Kuning & 0 & 0 & 0 \\
\hline 40 & L3C5 & Warna Kuning & 0 & 0 & 0 \\
\hline 41 & $\mathrm{~L} 4 \mathrm{C} 2$ & Warna Kuning & 0 & 0 & 0 \\
\hline 42 & L4C3 & Warna Kuning & 0 & 0 & 0.312304809 \\
\hline 43 & $\mathrm{~L} 4 \mathrm{C} 4$ & Warna Kuning & 0 & 0.125313283 & 5.569435769 \\
\hline 44 & L4C5 & Warna Kuning & 0 & 0 & 12.21111805 \\
\hline 45 & L5C2 & Warna Kuning & 0 & 0 & 0 \\
\hline
\end{tabular}




\begin{tabular}{llllll}
\hline 46 & L5C3 & Warna Kuning & 0 & 0 & 0.385175932 \\
\hline 47 & L5C4 & Warna Kuning & 0 & 0 & 3.716427233 \\
\hline 48 & L5C5 & Warna Kuning & 0 & 0 & 3.997501562 \\
\hline \hline
\end{tabular}

\section{Conclusion:}

Based on the characteristic value of the yellow egg yolk, the dominant color is the characteristic of the three eggs in the orange egg yolk, which does not have a dominant color value which is 0 , while for ordinary egg yolk, the dominant value is 38 with a value of 0.011392117 , and -43 with a value of 0.125313283 , while for pale eggs in the yellow position there is a dominant value of 38 with a value of $0.072871122,42$ characteristics with a value of $0.312304809,43$ characteristics with a value of $5.569435769,44$ th characteristic with a value of 12.21111805, The 46th characteristic with a value of 0.385175932 , the 47 th characteristic with a value of 3.716427233 the 48 th characteristic with a value of 3.997501562 .

\section{Conclusion}

1. Egg yellow extraction algorithm can produce a color bin feature, where the color bin of each yellow egg has a different distribution pattern. This proves that the resulting color bin features can be used to characterize the yellow-colored eggs, namely: orange egg yellow, ordinary egg yellow, and pale egg yellow.

2. The classification and recognition algorithm for egg yolk using Convolutional Neural Network resulted in a recognition rate of $94 \%$.

3. The implementation of the two algorithms above results in a software prototype that can extract egg-yellow color features and determination of egg content based on the introduction of the Convolutional Neural Network model.

\section{References}

1. Acharya, T. \& Ray, A.K. 2005. Image Processing: Principles and Applications. John Wiley \& Sons, Inc., Canada.

2. Andri Eko Umarudin. 2017. Identifikasi Kualitas Telur Ayam Ras Menggunaka Metode Decission Tree. Ahmad M. Sarhan, 2013, "Wavelet-based Feature Extraction For DNA Microarray Classification", Springer Science+Business Media B.V Artif Intell Rev (2013) 39:237249.

3. Almatsier, S. (2001). Prinsip dasar ilmu gizi. Jakarta: Gramedia Pustaka Utama.

4. Amirullah, I. K. 2003. Nutrisi Ayam Petelur. Seri Beternak Mandiri. Cetakan Pertama. Penerbit Lembaga Satu Gunungbudi, Bogor.

5. Azhar. Ryfial, Tuwohingide, Desmin, Kamudi, Dasrit, Sarimuddin., dan Suciati, Nanink, 2015, "Batik Image Classification Using SIFT Feature Extraction, Bag of Features and Support Vector Machine”, Procedia Computer Science 72(2015) 24-30, Elsevier.

6. Batoro J. 2008. Telur Omega. Malang. On line at http//www.malangkab.go.id./artikel/artikel.cfm [diakses tanggal 12 Januari 2012].

7. H.-D. Belitz · W. Grosch · P. Schieberle. 2009. Food Chemistry. 4th revised and extented Edition.

8. Boser, B., Guyan, I., dan Vapnik, V., 1992, “A Training Algorithm for Optimal Margin Classifiers", In Proceedings of the Fifht Annual Workshop on Computational Learning Theory, pp. 144-152, New York:ACM Press.

9. Bovšková, H, Míková, K, Panovská, Z.Czech Journal of Food Sciences 2014 Vol.32 No.3 pp.213-217 ref.9. Department of Food Analysis and Nutrition, Faculty of Food and Biochemical Technology, Institute of Chemical Technology Prague, Technická 5, 16628 Prague 6, Czech Republic.

10. Budiman, Fikri, 2015, "Studyof Wavelet Transformation Method for feature Extraction Characteristics Based In Identifying Authenticity Indonesiam Batik", International Conference on Information Technology and Engineering Aplication, Universitas Binadarma Palembang, 1:133-13.

11. Chung TK. 2002. Yellow and red carotenoids for eggs yolk pigmentation. 10" Annual ASA Southeast Asian Feed Technology and Nutrition Workshop. Thailand 6-7 juli 2002.

12. Delia B. Rodriguez-Amaya, Ph.D. 2001. A Guide To Carotenoid Analysis In Foods

13. Devi Utami Nur Indah Sari, Bambang Hidayat, Sjafril Darana, S.U. 2016. Detection Freshness And Quality Eggs With Color matching And Template Method. Vol.3, No.2 Agustus 2016.

14. Dwi Dinni Aulia Bakhtra, Rusdi dan Aisyah Mardiah, Jurnal Farmasi Higea, Vol. 8, No. 2, 2016.

15. Emha Taufiq Luthfi. 2007. Fuzzy c-means untuk clustering data (studi kasus : data performance mengajar dosen), Seminar Nasional Teknologi 2007 (SNT 2007) ISSN : 1978 -9777 Yogyakarta, 24 November 2007 
Juli Yanto was born in Jakarta, Indonesia 13th July, 1977. Bachelor of Information Systems at STMIK Swadharma, Masters in Computer Science at Universita Bunda Mulia and Doctor of Information Technology, Universias Gunadarma Jakarta Indonesia.

Email: julitomoko@gmail.com

Sarifuddin Madenda is a researcher and professor at Gunadarma University, Indonesia. He was born in Raha, Indonesia 7th April 1963. He finished his: B.S degree in Physic Instrumentation at University of Indonesia in 1989; M. S. degree in Electronics from INSA-Lyon, France in 1992; and Ph.D degree in Electronics and Image Processing from Universite de Bourgogne, France in 1995. He has also taught at UQO, Quebec - Canada since 2003. In fact, he is the Director of the Doctoral Program in Information Technology. His research interests are focused on image and video processing, multimedia data compression, content-based image and video capture, steganography (encryption, decryption, coding) and decoding of multimedia secret documents, real-time system architecture (FPGA and ASIC design).

E-mail: $\underline{\text { sarif@staff.gunadarma.ac.id }}$ 